\title{
Performance Comparison between ARIMAX, ANN and ARIMAX-ANN Hybridization in Sales Forecasting for Furniture Industry
}

\section{Usporedba performansi modela ARIMAX, ANN i hibridizacije ARIMAX-ANN u predviđanju prodaje za industriju namještaja}

\author{
Original scientific paper • Izvorni znanstveni rad \\ Received-prispjelo: 6. 12. 2017. \\ Accepted-prihvaćeno: 27. 11. 2018. \\ UDK: $630 * 79 ; 630 * 836$ \\ doi:10.5552/drind.2018.1770
}

\begin{abstract}
Manufacturing firms aim to increase their profits and reduce costs in a competitive and rapidly changing market. One of the most important ways to reach these goals is to forecast sales correctly. Furniture manufacturing, which is considered a prosperous and growing industry in Turkey, has an increasing trend related to the growth in construction and associated industries, increase in urban migration and increase in per capita income. Accuracy of sales forecasting in furniture industry is affected by external factors, such as consumer confidence index, producer price index, month of the year and number of vacation days as well as the time factor itself. This study aims to develop an Autoregressive Integrated Moving Average with external variables (ARIMAX) to forecast the total monthly sales of furniture products of a well-known manufacturer in Turkey. As a follow up study, a performance comparison between ARIMAX, artificial neural networks (ANNs) and ARIMAX-ANN hybridization is performed. In conclusion, results of performance measures demonstrate that hybrid model developed for each amount of product sales give better accuracy values than single methods. Overall, it is proved that using the ARIMAX and hybridization of this method with ANN are applicable for forecasting monthly sales of furniture products.
\end{abstract}

Keywords: ARIMAX, ANN, hybrid method, sales forecasting, furniture industry

SAŽETAK • Proizvodne tvrtke nastoje povećati dobit i smanjiti troškove na konkurentnom tržištu koje se brzo mijenja. Jedan od najvažnijih načina postizanja tih ciljeva jest što točnije predviđanje prodaje. Proizvodnja namještaja, koja se smatra perspektivnom i rastućom industrijom u Turskoj, bilježi sve veću potražnju, što se povezuje s rastom građevne industrije is njom povezanih djelatnosti te s povećanjem urbanih migracija i povećanjem dohotka po stanovniku. Na točnost predviđanja prodaje u industriji namještaja utječu vanjski činitelji kao što su indeks povjerenja potrošača, indeks proizvođačkih cijena, mjeseci u godini i broj dana godišnjih odmora, kao i faktor vremena. Cilj ove studije jest razvoj modela integriranoga autoregresivnog pomičnog prosjeka (Autoregressive Integrated Moving

\footnotetext{
Author is assistant professor at Munzur University, Engineering Faculty, Department of Mechanical Engineering, Tunceli, Turkey. ${ }^{2}$ Authors are assistant professors at Munzur University, Engineering Faculty, Department of Industrial Engineering, Tunceli, Turkey.

Autor je docent Sveučilišta Munzur, Inženjerski fakultet, Odjel za strojarstvo, Tunceli, Turska. ${ }^{2}$ Autori su docenti Sveučilišta Munzur, Inženjerski fakultet, Odjel za industrijsko inženjerstvo, Tunceli, Turska.
} 
Average - ARIMAX) s vanjskim varijablama za predviđanje ukupne mjesečne prodaje namještaja poznatog proizvođača u Turskoj. U nastavku istraživanja provedena je usporedba performansi modela ARIMAX, umjetnih neuronskih mreža (ANNs) i hibridnog modela ARIMAX-ANN. Dobiveni rezultati pokazuju da hibridni model razvijen za prodaju svakog proizvoda daje bolju točnost od pojedinačnih modela. Zaključno, dokazano je da se za predviđanje mjesečne prodaje namještaja može primijeniti hibridizacija modela ARIMAX s ANN-om.

Ključne riječi: ARIMAX, ANN, hibridna metoda, predviđanje prodaje, industrija namještaja

\section{INTRODUCTION}

\section{UVOD}

The demand for furniture products in Turkey has increased rapidly with the recent development in construction industry, increase in urban population and personal income level (Hazır et al., 2016; Turkey Furniture Products Council Industry Report, 2013). However, it is difficult to forecast this increase considering the multiplicity and internal interactions of the affecting factors. Statistical methods, such as regression or ARIMAX and data mining methods as ANNs have been frequently applied in sales forecasting by numerous researchers since they have the ability to solve complicated interactions affected by internal and external environments (Kuo et al., 2002; Luxhøj et al., 1996). Bearing this issue in mind, this study attempts to develop a time series model with external variables to forecast monthly sales of furniture products using ARIMAX, ANN and ARIMAX-ANN model.

In the related literature, researchers proposed new forecasting methods, evaluated the performance of existing ones or modified the existing ones depending on applications in sales forecasting (Arunraj and Ahrens, 2015). The methods include regression, timeseries related methods and advanced machine learning related methods. Although sales forecasting in the context of all sectors has been studied by many researchers, in the area of furniture sales forecasting, the publications are very few when compared to other fields. Hazır et al. (2016) studied sales forecasting of Turkish furniture industry by ANN and multiple linear regression (MLR), and provided a road map for vision 2023. Data between 2004 and 2013 was used for analysis. As a result of the study, 24 billion dollars and 21 billion dollars demands were predicted by MLR analysis and ANN methodology, respectively. They stated that these results may be evaluated as the possible retail values for Turkish furniture industry within the target of vision 2023. Mahbub et al. (2013) proposed an ANN model to forecast the optimum demand considering time variables of the year, festival period, promotional programmes, holidays, number of advertisements, cost of advertisements, number of workers and availability. A feed-forward backpropagation ANN with 13 hidden neurons in one hidden layer as the optimum network was preferred. The model was confirmed with a furniture product data of a renowned furniture company. The model was compared with Brown's double smoothing. The results of the study show that ANN model performs much better than the linear Brown's double smoothing model. Oblak et al. (2012) applied two quantitative methods named Holt-Winters method of exponent smoothing of higher orders and linear regression of the 1st order for forecasting of parquet sales. Parquet sales data by month in the years 2000 to 2009 was used in the models and the best result was obtained with the use of Holt-Winters multiplicative model of exponent smoothing of higher orders. In conclusion, it was suggested that the proposed model can be applied for forecasting optimum demand level of furniture products in any furniture company. As stated by Arunraj and Ahrens (2015), there is no common forecasting model that can be applied to different kinds of problems. Accuracy of the forecasting models can be improved by hybridized models rather than by a single model. Therefore, in this study, an ARIMAX model was developed to forecast the total monthly sales of furniture products of a well-known Turkish manufacturer and a performance comparison was performed between the models of ARIMAX, ANN and ARIMAX-ANN hybridization in order to improve the accuracy of the proposed framework.

Apart from forecasting sales in the furniture industry, the forecasting methods are used in different fields of application. Fabianová et al. (2016) presented a sale forecasting using the software tool for risk analysis. It was carried out based on time series analysis, forecasting and statistics analysis. Forecasting was performed using two different approaches: when considering simple seasonality of sales and when considering sale seasonality along with the impact of known events on demand. Subsequent forecasting is focused on the identification and analysis of risk factors using Monte-Carlo Simulation (MCS). Anggraeni et al. (2015) and Lee and Hamzah (2010) studied sales forecasting for clothing industry. While the first study made a performance comparison between ARIMA and ARIMAX in Moslem kids' clothes sales forecasting, the second one dealt with forecasting sales data with Ramadhan effect by ARIMAX modelling. Results of studies by Anggraeni et al. (2015) show that ARIMAX model is better than ARIMA model in accuracy level of training, testing and next time forecasting processes. In conclusion of the study by Lee and Hamzah (2010), it is observed that ARIMAX yields better forecast at outsample data compared to the decomposition method and Seasonal Autoregressive Integrated Moving Average (SARIMA), and neural networks. Arunraj and Ahrens (2015) proposed hybridization of SARIMAQuantile Regression (QR) model to food sales forecasting. The results show that the SARIMA-MLR and -QR models yield better forecasts at out-sample data when compared to seasonal naïve forecasting, traditional SARIMA, and multi-layered perceptron neural network models. Unlike the SARIMA-MLR model, 
the SARIMA-QR model provides better prediction. Murlidharan and Menezes (2013) proposed a different concept in sales forecasting "Frequent pattern miningbased sales forecasting". In some studies, ANN was used in combination with Genetic Algorithm (GA) in order to select the appropriate input variables to the models (Doganis et al., 2006; Kuo, 2001). Doganis et al. (2006) applied ANN-GA combination for short shelf-life food products sales forecasting. Kuo (2001) proposed a model based on fuzzy neural network with initial weights generated by GA. Similarly, Kuo et al. (2002) integrated ANNs and fuzzy neural networks

Table 1 Review of sales forecasting application studied in literature

Tablica 1. Pregled primjene metoda za predviđanje prodaje iz literature

\begin{tabular}{|c|c|c|c|}
\hline $\begin{array}{l}\text { Study } \\
\text { Literatura }\end{array}$ & $\begin{array}{l}\text { Application industry } \\
\text { Industrija primjene }\end{array}$ & $\begin{array}{l}\text { Methods used } \\
\text { Primijenjene } \\
\text { metode }\end{array}$ & $\begin{array}{l}\text { Novelty } \\
\text { Novina }\end{array}$ \\
\hline $\begin{array}{l}\text { Fabianová et al. } \\
\text { (2016) }\end{array}$ & $\begin{array}{l}\text { Retailing } \\
\text { maloprodaja }\end{array}$ & $\begin{array}{l}\text { ARIMA, MLR, } \\
\text { MCS }\end{array}$ & $\begin{array}{l}\text { Sales forecasting considering data uncertainty / predviđanje } \\
\text { prodaje uzimanjem nesigurnosti podataka u obzir }\end{array}$ \\
\hline $\begin{array}{l}\text { Anggraeni et al. } \\
(2015)\end{array}$ & $\begin{array}{l}\text { Clothing } \\
\text { proizvodnja odjeće }\end{array}$ & $\begin{array}{l}\text { ARIMA, } \\
\text { ARIMAX }\end{array}$ & $\begin{array}{l}\text { Performance comparison between ARIMA and ARIMAX in } \\
\text { Moslem kids' clothes sales forecasting / usporedba perfor- } \\
\text { mansi metoda ARIMA i ARIMAX u predviđanju prodaje } \\
\text { odjeće za muslimansku djecu }\end{array}$ \\
\hline $\begin{array}{l}\text { Oblak et al. } \\
(2012)\end{array}$ & $\begin{array}{l}\text { Forestry } \\
\text { šumarstvo }\end{array}$ & $\begin{array}{l}\text { Holt-Winters, } \\
\text { Linear regression } \\
\text { of the } 1 \text { st order }\end{array}$ & $\begin{array}{l}\text { Forecasting of parquet sales } \\
\text { predviđanje prodaje parketa }\end{array}$ \\
\hline $\begin{array}{l}\text { Arunraj and } \\
\text { Ahrens (2015) }\end{array}$ & $\begin{array}{l}\text { Food } \\
\text { proizvodnja hrane }\end{array}$ & $\begin{array}{l}\text { SARIMAX, MLR, } \\
\text { QR }\end{array}$ & $\begin{array}{l}\text { Hybridization of SARIMA-QR model to food sales forecast- } \\
\text { ing / hibridizacija modela SARIMA-QR za predviđanje } \\
\text { prodaje hrane }\end{array}$ \\
\hline $\begin{array}{l}\text { Hazır et al. } \\
(2016)\end{array}$ & $\begin{array}{l}\text { Furniture } \\
\text { proizvodnja namještaja }\end{array}$ & ANN, MLR & $\begin{array}{l}\text { Sales forecasting in Turkey by ANN and MLR and providing } \\
\text { a framework plan for } 2023 \text { vision } \\
\text { prognoza prodaje u Turskoj prema ANN-u i MLR-u te izrada } \\
\text { okvirnog plana za viziju } 2023 \text {. }\end{array}$ \\
\hline $\begin{array}{l}\text { Mahbub et al. } \\
\text { (2013) }\end{array}$ & $\begin{array}{l}\text { Furniture } \\
\text { proizvodnja namještaja }\end{array}$ & $\begin{array}{l}\text { ANN, Brown's } \\
\text { double smoothing }\end{array}$ & $\begin{array}{l}\text { A neural approach to furniture product sales forecasting / } \\
\text { neuronski pristup predviđanju prodaje namještaja }\end{array}$ \\
\hline $\begin{array}{l}\text { Murlidharan } \\
\text { and Menezes } \\
(2013)\end{array}$ & N/A & $\begin{array}{l}\text { Frequent pattern } \\
\text { mining }\end{array}$ & $\begin{array}{l}\text { Frequent pattern mining-based sales forecasting / procjena } \\
\text { prodaje utemeljena na rudarenju podataka i pronalaženju } \\
\text { čestih modela }\end{array}$ \\
\hline $\begin{array}{l}\text { Lee and } \\
\text { Hamzah (2010) }\end{array}$ & $\begin{array}{l}\text { Clothing } \\
\text { proizvodnja odjeće }\end{array}$ & ARIMAX & $\begin{array}{l}\text { ARIMAX for forecasting sales data with Ramadhan effect / } \\
\text { ARIMAX za predvidanje podataka o prodaji Ramadhanovim } \\
\text { ućinkom }\end{array}$ \\
\hline $\begin{array}{l}\text { Doganis et al. } \\
\text { (2006) }\end{array}$ & $\begin{array}{l}\text { Food } \\
\text { proizvodnja hrane }\end{array}$ & ANN, GA & $\begin{array}{l}\text { Sales forecasting for short shelf-life food products based on } \\
\text { ANN-GA combination } \\
\text { predviđanje prodaje prehrambenih proizvoda s kratkim } \\
\text { rokom trajanja na temelju kombinacije ANN-GA }\end{array}$ \\
\hline $\begin{array}{l}\text { Kuo et al. } \\
(2002)\end{array}$ & N/A & FNN, ANN & $\begin{array}{l}\text { Integration of ANNs and fuzzy neural networks with fuzzy } \\
\text { weight elimination / integracija ANN i neizrazitih neuronskih } \\
\text { mreža s neizrazitom eliminacijom težine }\end{array}$ \\
\hline Kuo (2001) & $\begin{array}{l}\text { Convenience store } \\
\text { minimarket }\end{array}$ & FNN, GA & $\begin{array}{l}\text { A sales forecasting based on fuzzy neural network with } \\
\text { initial weights generated by genetic algorithm / prognoz- } \\
\text { iranje prodaje utemeljeno na neizrazitoj neuronskoj mreži s } \\
\text { inicijalnim težinama generiranima genetskim algoritmom }\end{array}$ \\
\hline $\begin{array}{l}\text { Alon et al. } \\
(2001)\end{array}$ & $\begin{array}{l}\text { Retailing } \\
\text { maloprodaja }\end{array}$ & $\begin{array}{l}\text { ANN, MLR, } \\
\text { Winters ES, } \\
\text { Box-Jenkins } \\
\text { ARIMA } \\
\end{array}$ & $\begin{array}{l}\text { A comparison of ANNs and traditional methods in forecast- } \\
\text { ing aggregate retail sales / usporedba ANN-ova i tradicional- } \\
\text { nih metoda u predviđanju agregirane maloprodaje }\end{array}$ \\
\hline Yip et al. (1997) & N/A & ANN & $\begin{array}{l}\text { Application of ANNs in sales forecasting primjena } A N N \text {-ova } \\
\text { u predviđanju prodaje }\end{array}$ \\
\hline $\begin{array}{l}\text { Luxhøj et al. } \\
\text { (1996) }\end{array}$ & $\begin{array}{l}\text { Consumer goods } \\
\text { roba široke potrošnje }\end{array}$ & ES, MLR, ANN & $\begin{array}{l}\text { Hybrid econometric-neural network model for sales } \\
\text { forecasting / hibridni ekonometrijski neuronski model za } \\
\text { prognozu prodaje }\end{array}$ \\
\hline
\end{tabular}

Abbreviations: MLR (Multiple Linear Regression); QR (Quantile Regression); ES (Exponential Smoothing); FNN (Fuzzy neural network); GA (Genetic Algorithm); MCS (Monte-Carlo simulation); ARIMA (Autoregressive Integrated Moving Average); ARIMAX (Autoregressive Integrated Moving Average with external variables); SARIMAX (Seasonal Autoregressive Integrated Moving Average with external variables)

Kratice: $M L R$ - višestruka linearna regresija; $Q R$ - kvantilna regresija; ES - eksponencijalno izravnavanje; FNN - neizrazita neuronska mreža; GA - genetički algoritam; MCS - Monte Carlo simulacija; ARIMA - integrirani autoregresivni pomični prosjek; ARIMAX - integrirani autoregresivni pomični prosjeks vanjskim varijablama; SARIMAX - sezonalni integrirani autoregresivni pomični prosjek s vanjskim varijablama 
with fuzzy weight elimination for the first time in literature. According to the results of the study, the proposed model performs more accurately than the conventional statistical method and single ANN model. Alon et al. (2001) made a comparison of ANNs and traditional methods in forecasting aggregate retail sales. Yip et al. (1997) studied an application of ANNs in sales forecasting. Unlike Yip et al. (1997), Luxhøj et al. (1996) focused on a hybrid econometric-neural network model for sales forecasting. Using of this hybrid method yielded a modest $2.3 \%$ reduction in the mean absolute percentage error (MAPE) when compared with the current qualitative approach used by the company. The above-mentioned literature review is summarized in Table 1.

\section{MATERIAL AND METHODS 2. MATERIJAL I METODE}

\subsection{Data set}

2.1. Set podataka

This study uses monthly sales of furniture products (dining room, bedroom, teen room, sitting group and armchair) measured in numbers from one of the biggest furniture factories as a case study from January 2009 to December 2015. The selected factory is located in Black sea region of Turkey. Figure 1 illustrates the monthly sales data of furniture products for a seven-year time period in a time series plot. The mean sales per month is about 140,114, 60, 115 and 531, respectively, for the products of dining room, bedroom, teen room, sitting group and armchair. This time series is highly periodic, but it is easy to observe the monthly patterns. Especially in summer, the sales are observed at the peak point. This type of month effects can be recognized by considering the months from January to November as dummy variables (0 and 1$)$. The refer- ence month is December, so coefficients of other months may be interpreted relative to this month.

In Figure 2, the box plot displays the median monthly sales from January to December. From this figure, it is evident that the highest sales usually occur in August. May, June, July, September and October are the next highest sales months. The box-plot also shows information about extreme values and outliers, which occur mainly due to holidays and other variables. However, the median of monthly sales for May \& June and September \& October are similar; sales dispersion is higher in June than in July.

In addition to the month of the year affect, three variables are used as input parameters to forecast sales value of a furniture company. The first one is consumer confidence index (CCI). CCI is an aggregate of four sub-indices. Two of them are based on expectations regarding household finances, while the other two are based on expectations about economy-wide developments (Jansen and Nahuis, 2003). The second input variable is producer price index (PPI). PPI is an aggregate of over 1500 components. Each component is a monthly index of the national average price for some producer goods. The price pertains to the first transaction after production of the good. This is a transaction between firms rather than between businesses and consumers (Peltzman, 2000). Other input parameters are number of vacation days in the related month of the year in Turkey. Distribution of number of vacation days for the data set is given Figure 3.

The output parameters are monthly sales of dining room, bedroom, teen room, sitting group and armchair. Inputs, outputs and applied methods are shown in Figure 4.

Data about input and output variables were collected for 84 months from January 2009 to December 2015 from the furniture company. Descriptive statistics

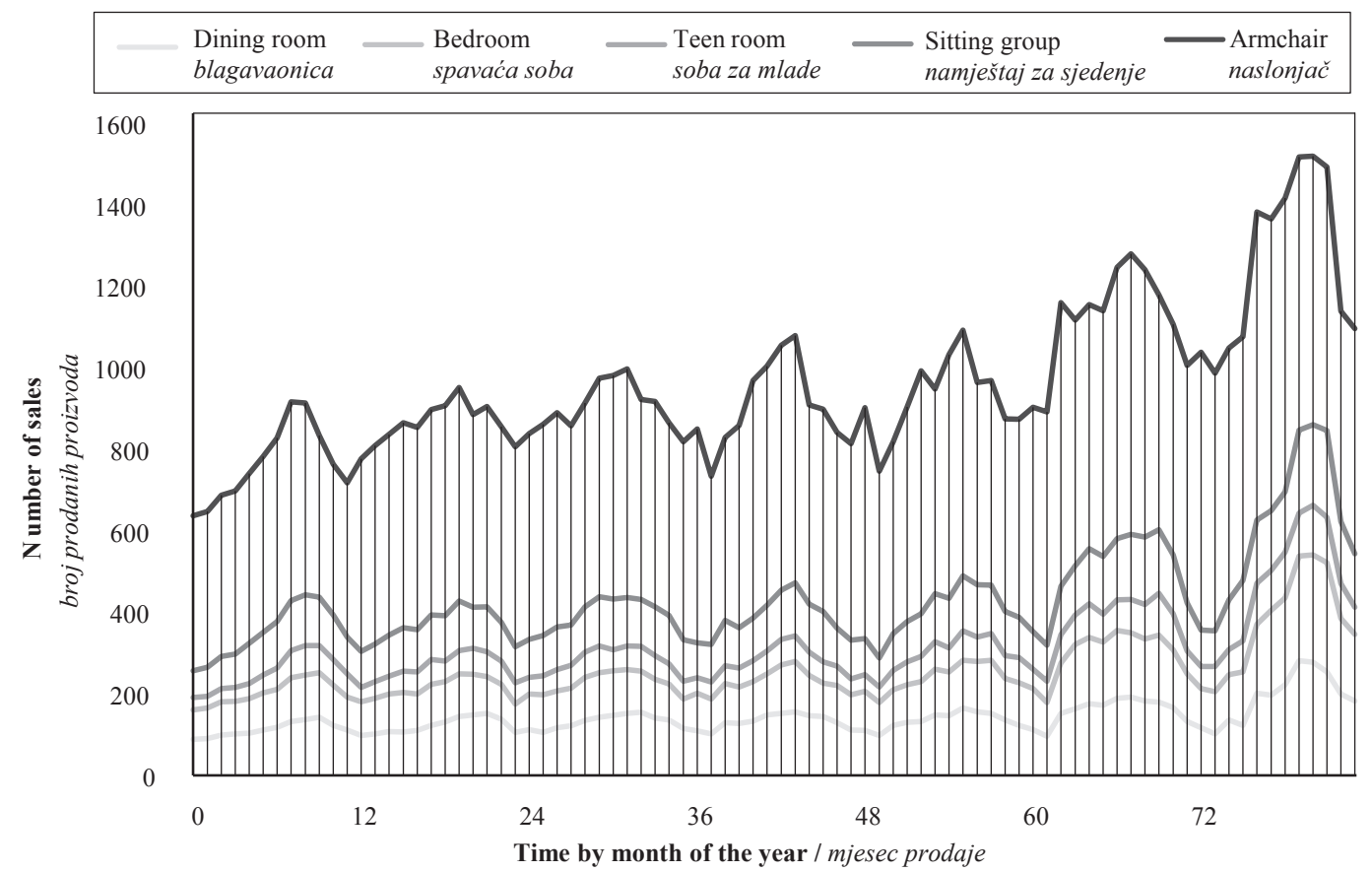

Figure 1 Sales of furniture products between 2009 and 2015

Slika 1. Prodaja namještaja između 2009. i 2015. godine 
Yucesan, Gul, Celik: Performance Comparison between ARIMAX, ANN and ...

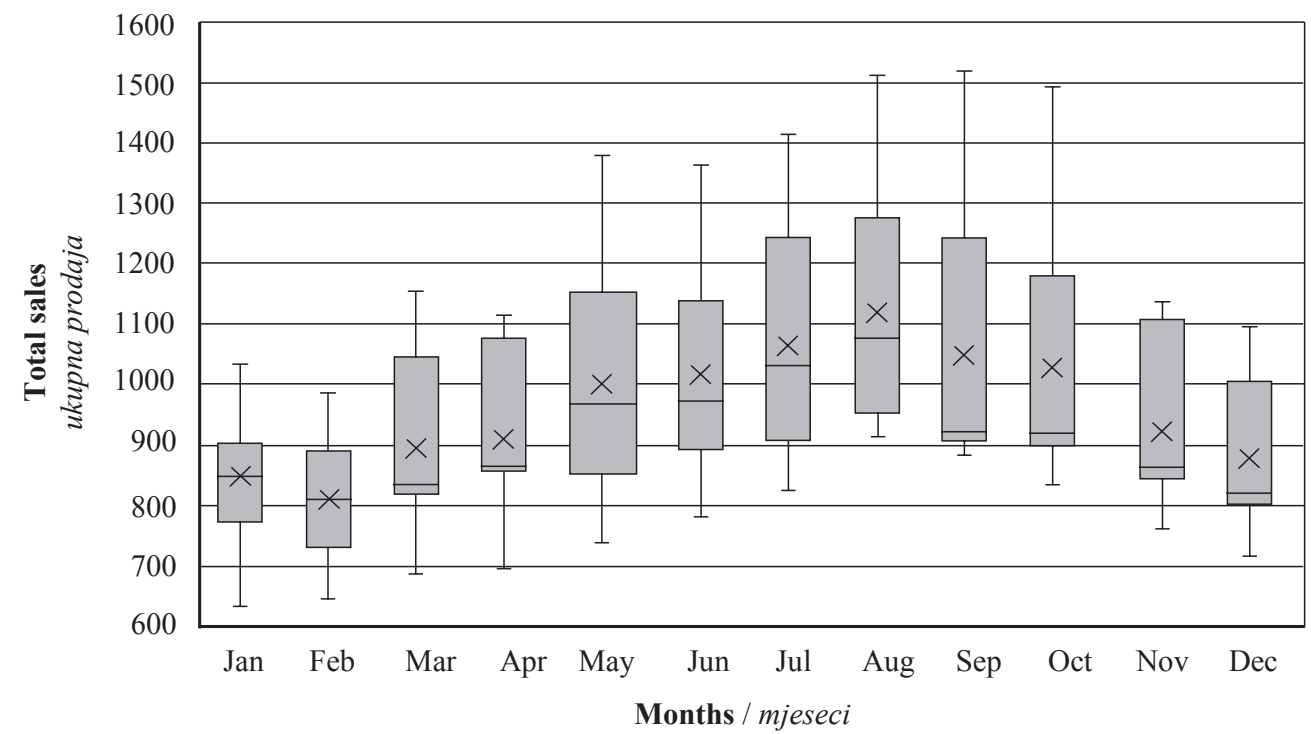

Figure 2 Box-plot for total monthly sales of furniture products from January to December

Slika 2. Box-plot za ukupnu mjesečnu prodaju namještaja od siječnja do prosinca

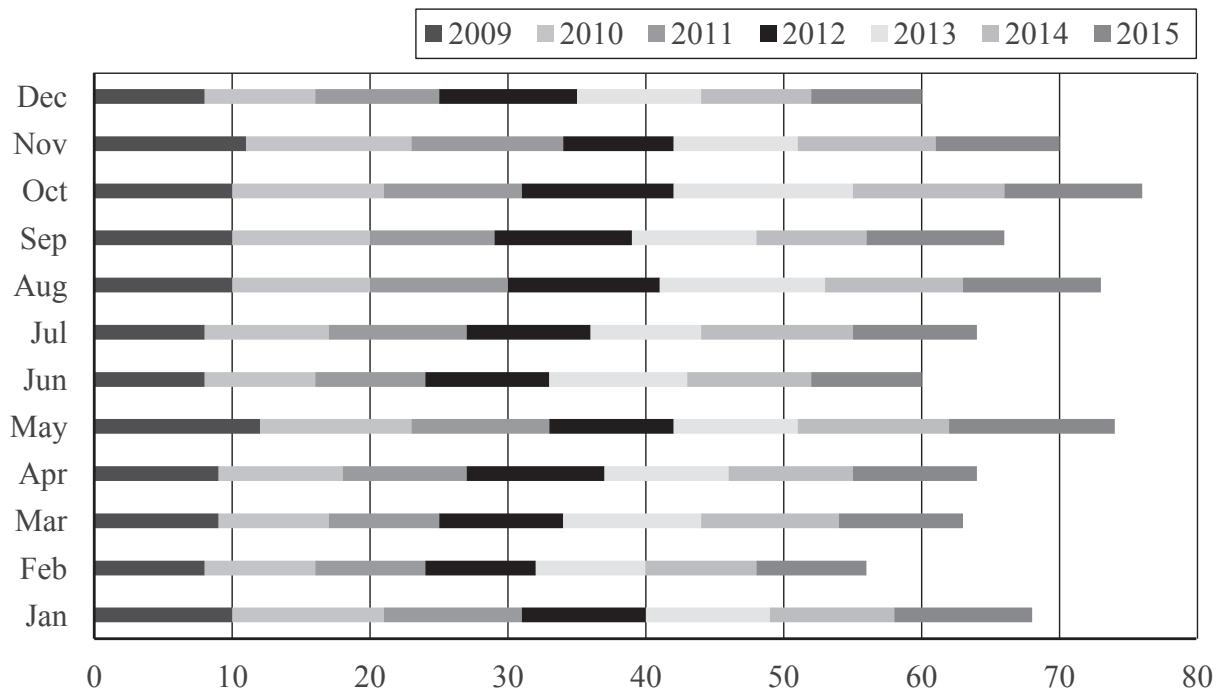

Figure 3 Distribution of number of vacation days by year/month in Turkey

Slika 3. Raspodjela broja dana godišnjeg odmora po godini/mjesecu u Turskoj

Table 2 Descriptive statistics for total monthly sales (January 2009 - December 2015)

Tablica 2. Deskriptivna statistika ukupne mjesečne prodaje (siječanj 2009. - prosinac 2015.)

\begin{tabular}{|l|c|c|c|c|c|c|c|c|c|c|c|}
\hline \multicolumn{1}{|c|}{$\begin{array}{c}\text { Output Variable } \\
\text { Izlazne varijable }\end{array}$} & $\begin{array}{c}\text { Count } \\
\text { Broj } \\
\text { mjese- } \\
\text { ci }\end{array}$ & $\begin{array}{c}\text { Mean } \\
\text { Sred- } \\
\text { nja } \\
\text { vrijed- } \\
\text { nost }\end{array}$ & $\begin{array}{c}\text { SE Mean } \\
\text { Srednja } \\
\text { vrijednost } \\
\text { stand. } \\
\text { pogreške }\end{array}$ & $\begin{array}{c}\text { St. Dev } \\
\text { Stand- } \\
\text { ardna } \\
\text { devi- } \\
\text { jacija }\end{array}$ & $\begin{array}{c}\text { Vari- } \\
\text { ance } \\
\text { Varija- } \\
\text { nca }\end{array}$ & $\begin{array}{c}\text { Mini- } \\
\text { mum } \\
\text { Mini- } \\
\text { mum }\end{array}$ & Q1 & $\begin{array}{c}\text { Me- } \\
\text { dian } \\
\text { Medi- } \\
\text { jan }\end{array}$ & Q3 & $\begin{array}{c}\text { Maxi- } \\
\text { mum } \\
\text { Mak- } \\
\text { simum }\end{array}$ & $\begin{array}{c}\text { Range } \\
\text { Raspon }\end{array}$ \\
\hline $\begin{array}{l}\text { Dining room sales } \\
\text { prodaja blagovaonica }\end{array}$ & 84 & 140.39 & 4.17 & 38.18 & 1457.81 & 88 & 111.3 & 134 & 152 & 281 & 193 \\
\hline $\begin{array}{l}\text { Bedroom sales } \\
\text { prodaja spavaćih soba }\end{array}$ & 84 & 114.17 & 4.53 & 41.56 & 1727.22 & 70 & 89.25 & 100 & 122 & 268 & 198 \\
\hline $\begin{array}{l}\text { Teen room sales } \\
\text { prodaja soba za mlade }\end{array}$ & 84 & 60.44 & 2.09 & 19.15 & 366.85 & 29 & 47.25 & 57 & 66.75 & 122 & 93 \\
\hline $\begin{array}{l}\text { Sitting group sales } \\
\text { prodaja namještaja za } \\
\text { sjedenje }\end{array}$ & 84 & 115.24 & 3 & 27.51 & 756.98 & 65 & 95.75 & 111 & 124 & 212 & 147 \\
\hline $\begin{array}{l}\text { Armchair sales } \\
\text { prodaja naslonjača }\end{array}$ & 84 & 530.98 & 9.4 & 86.13 & 7419.11 & 370 & 480.5 & 504.5 & 596.75 & 755 & 385 \\
\hline
\end{tabular}




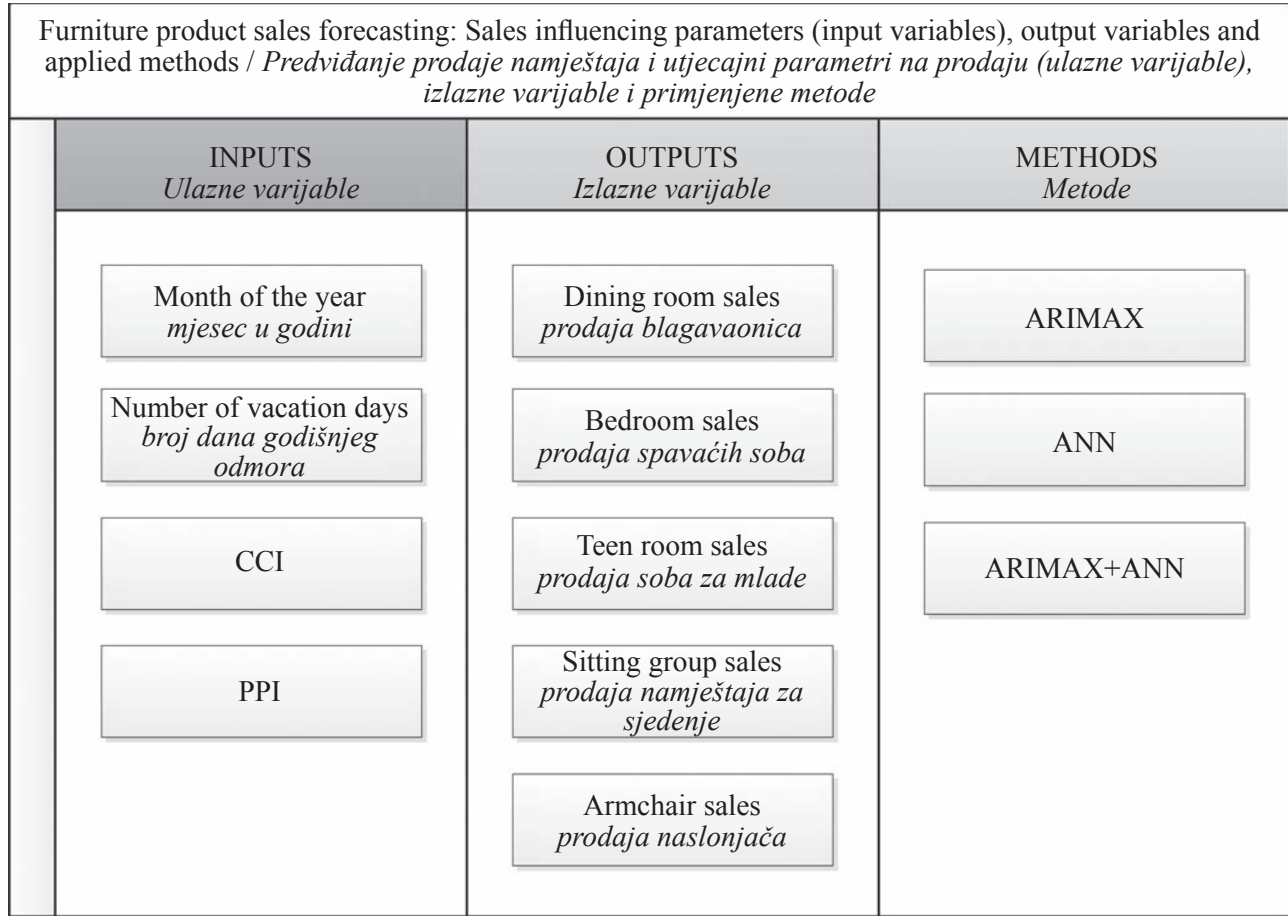

Figure 4 Presentation of inputs and output variables and applied methods

Slika 4. Prikaz ulaznih i izlaznih varijabli i primijenjenih metoda

for each output variable are presented in Table 2. The values of CCI and PPI are ratios that have a mean of 72.85 and 209.2, respectively. Mean number of vacation days in the studied data set is 9.45 per month. The reason for considering this input variable in our proposed comparative framework model stems from the fact that decision makers in furniture industry are of the opinion that sales increase in vacation days.

\subsection{Research methods}

\subsection{Metode istraživanja}

In this study, three forecasting methods including single (ARIMAX, ANN) and hybrid (ARIMAX-ANN) methods were investigated in order to find the best method that accurately fits the data. Detailed descriptions of each method are presented in the following subsections.

\subsubsection{ARIMAX \\ 2.2.1. ARIMAX}

Recently, ARIMA has been studied by many researchers who used time series. However, when using ARIMA model, only one variable can be used, so it is not adequate to express real problems. Complex problems always need more the one variable in order to explain problems effectively. Therefore, it is necessary to build a multivariate ARIMAX model (Fan et al. 2009; Jalalkamali et al. 2015).

The ARIMAX model (Bierens, 1987) is a generalization of the ARIMA model, which is capable of incorporating an external input variable $(X)$. The ARIMAX model assumes the form

$\left(1-\sum_{s}^{p} \alpha_{s} L_{s}\right) \Delta y_{t}=\mu+\sum_{s=1}^{q} \beta_{s} L^{s} x_{t}+\left(1+\sum_{s=1}^{r} \gamma_{s} L^{s}\right) e^{t}$

where $L$ is usual lag operator. $\gamma_{\mathrm{s}} L^{\mathrm{s}}=y_{(\mathrm{t}-\mathrm{s})}, \Delta y_{\mathrm{t}}=y_{\mathrm{t}}-y_{\mathrm{t}-1}, \mu$ $\in, \alpha_{\mathrm{s}} \in R, \beta_{\mathrm{s}} \in R^{\mathrm{k}}$ and $\gamma_{\mathrm{s}} \in R$ are the unknown param- eters and $e_{t}^{\prime} s$ are the errors (Arya et al., 2015). ARIMAX model consists of four parts. These parts are Auto Regressive (AR), Integrated (I), Moving Average (MA), and Exogenous Variable (X) (Sutthichaimethee and Ariyasajjakorn, 2017).

\subsubsection{ANN \\ 2.2.2. ANN}

ANNs are machine learning algorithms that aim to solve the computational processes in specific areas by using a large number of interconnected processing elements (Gul and Guneri, 2015; 2016a; 2016b; Yucesan et al. 2017; Onat and Gul, 2018). They are applied to the problems on prediction, clustering, classification, and detection of abnormalities (Pusat et al. 2016). The computational elements used in different ANN models are known as artificial neurons (Guneri and Gumus, 2008; 2009). The model of an artificial neuron is given in Figure 5.

Where $x_{1}, x_{2}, \ldots, x_{p}$ are the input signals; $w_{k l}, w_{k 2}$, $\ldots, w_{k p}$ are the weights of neuron $k$, and, $u_{k}$ is the linear combiner output, while $\theta_{k}$ denotes the threshold. Furthermore, $\Phi()$ is the activation function; and $y_{k}$ is the output of the neuron. The first layer known as the "input" layer and the last one, which is called the "output" layer, are used to get information from inside and outside the network, respectively. The middle layers considered as "hidden" layers are vital for the network to convert certain input patterns into appropriate output patterns (Akkoyunlu et al., 2015; Somoza and Somoza, 1993). The flow of information is passed through the network by linear connections and linear or nonlinear transformations. The error between the actual and predicted values is calculated. Then, a minimization procedure is used to adjust the weights between two connection layers, i.e. for back 


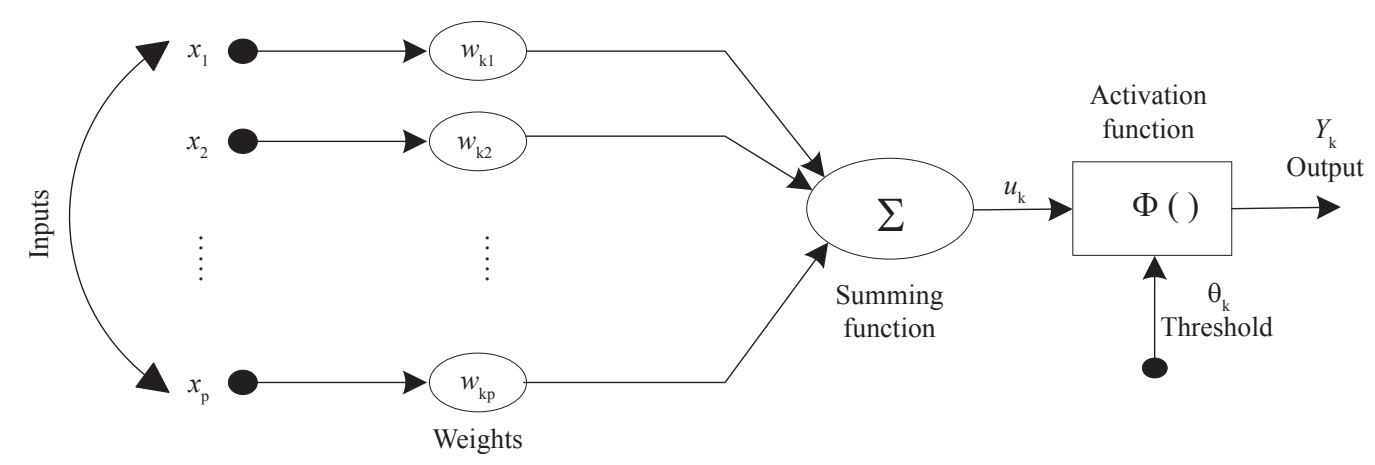

Figure 5 Flow chart of an artificial neuron (Yucesan et al. 2017)

Slika 5. Dijagram toka umjetnog neurona (Yucesan et al., 2017.)

propagation model starting backwards from the output layer to input layer. There are many minimization procedures based on different optimization algorithms, such as Quasi-Newton, and Levenberg-Marquardt, gradient descent and conjugate gradient methods. In ANN models, there is a practical problem in network architecture (number of hidden layers and units in each layer) and network properties (error and activation functions). The design of hidden layer is dependent on the selected learning algorithm (Kröse et al., 1993). The more layers and neurons, the more complex dependencies the network can model. One of the other important properties of an ANN model is the activation function for the hidden layer. Linear, logistic and hyperbolic tangent are the most common functions followed in the literature. In ANNs, some controllable factors are available in order to aid the learning of selected algorithm such as Learning Rate and Momentum. They are control parameters used by several learning algorithms, which affect the changing of weights. The higher learning rates cause higher weight changes during each iteration. The greater the momentum, the more the current weight change is affected by the weight change that took place during the previous iteration.

\subsubsection{ARIMAX-ANN hybrid method}

\subsubsection{Hibridna metoda ARIMAX-ANN}

In time series forecasting, hybrid models are developed apart from single models in order to reduce risk of failure and also obtain more accurate results (Khashei and Bijari, 2010). ARIMAX models are insufficient to solve complex nonlinear problems. On the other hand, using ANNs to solve problems yields dicey results. For that reason, if a distinctive framework of problems is not know, hybrid methodology that contains advance sides of ARIMAX and ANN models can be a good solution. Therefore, we combined ARIMAX and ANN model in sales forecasting for furniture industry. In the first step, ARIMAX model is used to calculate residual of the model. In the second step, ANN model is applied with independent variables including residuals of ARIMAX model as input variables.

Since ARIMAX model cannot capture the nonlinear structure of the data, the residuals of the linear model will contain information about nonlinearity. The results from the neural network can be used as predictions of the error terms for the ARIMA model (Zhang 2003; Xu et al., 2016).

Step 1: ARIMAX model is applied to analyze the linear part of the problem. First, model identification is performed by using graphs, statistics, autocorrelation function (ACF), partial autocorrelation function (PACF) and transformations. The dependent variable is determined as stationary. Least squares are used to determine the valid model and variables. Finally, forecast verification and reasonableness is performed in order to track performance and determine the validity of forecast, then fit $\left(y_{\mathrm{t}}, y_{\mathrm{t}-1} \ldots y_{\mathrm{t}-\mathrm{n}}\right)$ and calculate residuals $\left(e_{\mathrm{t}}, e_{\mathrm{t}-1} \ldots e_{\mathrm{t}-\mathrm{n}}\right)$ (Areekul et al., 2010).

Step 2: ANN model is applied considering the variables of month of the year, number of vacation days, PPI, CCI and residuals which are calculated in ARIMAX model as input variables of the model. To measure performance of ANN model, mean squared error (MSE), network error (average train error and average test error), absolute relative error (ARE), mean absolute percentage error (MAPE) and $R$-squared $\left(R^{2}\right)$ can be used. $R^{2}$ and MAPE are defined as in Eqs. (2)-(3).

$$
R^{2}=1-\frac{S S_{\text {residuals }}}{S S_{\text {total }}}
$$

where $S S_{\text {total }}$ refers to the total sum of squares (proportional to the variance of the data), and $S S$ indicate the sum of squares of residuals, also called the residual sum of squares.

$$
\text { MAPE }=\frac{100}{n} \sum_{i=1}^{n}\left|\frac{y_{i}-f_{i}}{y_{i}}\right|
$$

Where $f_{\mathrm{i}}$ is vector of $n$ forecasting, and $y_{\mathrm{i}}$ is the vector of actual values.

\subsubsection{Proposed comparative framework}

\subsubsection{Predloženi usporedbeni okvir}

The proposed comparative framework used in this study consists of four stages as given in Figure 6. It includes a time series (ARIMAX), an ANN and a hybrid (ARIMAX-ANN) model. The "best" model for each stage was identified, and then these models were compared at the last stage of the framework. Measures of solution adequacy are evaluated under MAPE values. Moreover, plots regarding actual vs. predicted values for each furniture product are demonstrated. 
Yucesan, Gul, Celik: Performance Comparison between ARIMAX, ANN and ............
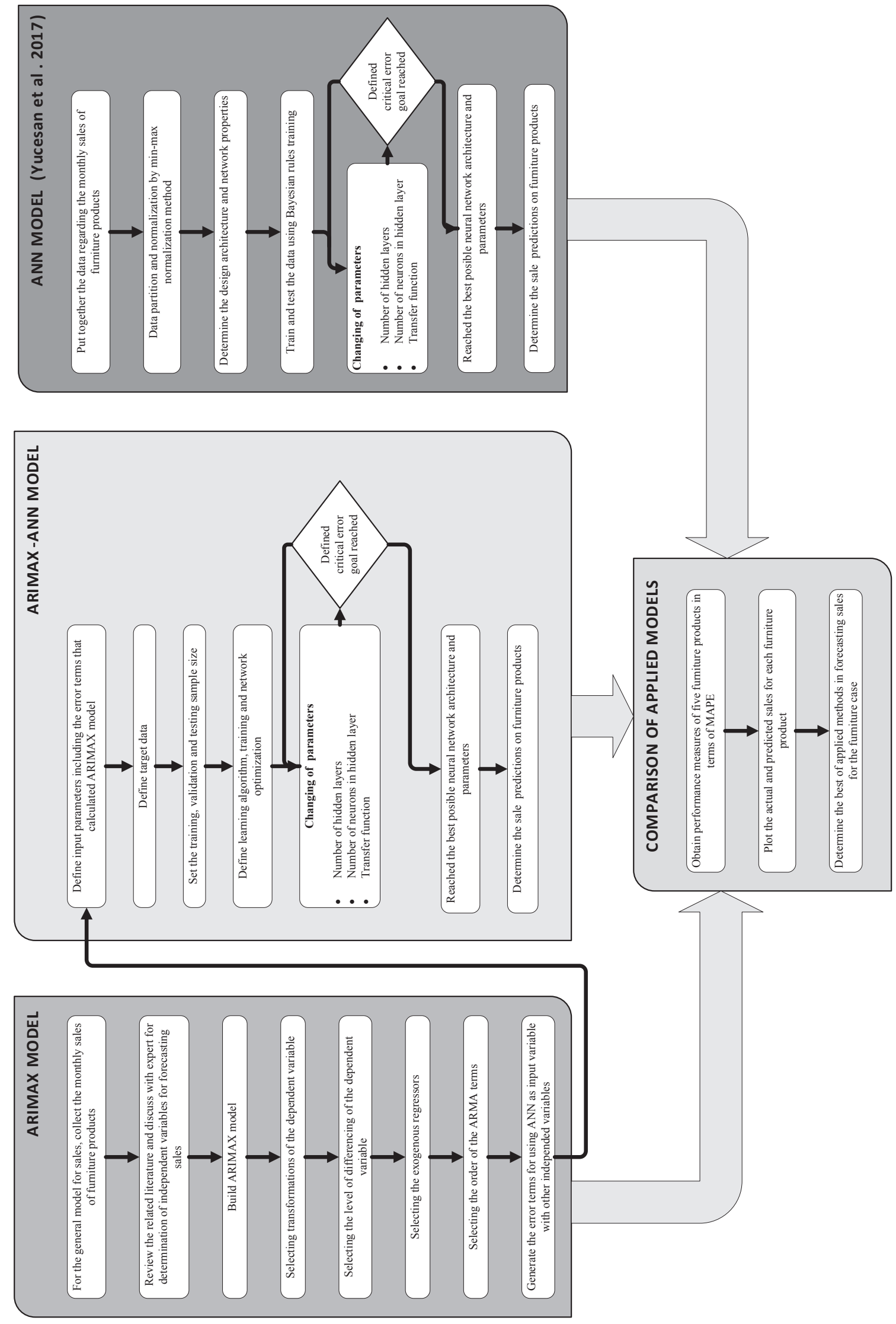

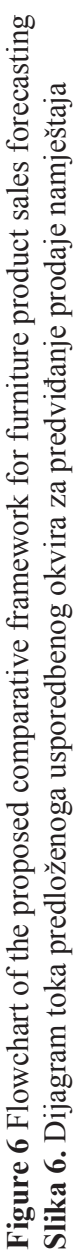




\section{RESULTS AND DISCUSSION}

\section{REZULTATI I RASPRAVA}

\subsection{Results of application case}

\subsection{Rezultati za promatranu tvrtku}

In this study, a comparative framework to forecast total monthly sales of furniture products was developed. To achieve this aim, a case study was carried out in a furniture product manufacturing company located in Black Sea region of Turkey. In the first stage, an ARIMAX model is proposed. We collected the monthly sales data detailed above. It includes 84 data points for each output variable corresponding to sevenyear data. For all of the ARIMAX modeling processes, EViews 10.0 was used. The ARIMAX model used for forecasting was split into three steps:

(1) Transformations of the dependent variables were made and the level of differencing was determined. Transformations of monthly sales of dining room, bedroom, teen room and armchair were made by differencing. The transformation of the sales of sitting group was arranged based on both logarithmic and differencing operations.

(2) The external independent variables were determined as mentioned in previous sub-sections (Subsection 2.2.1). The ARIMAX model developed to forecast teen room sales in our case study has the following external variables (Eq. 4).

$$
\begin{aligned}
D\left(y_{t}\right)= & \sum_{i=1}^{12} c_{j} M_{j, t}+d C C I_{t}+e P P I_{t}+f V_{t}+\rho_{1} \vartheta_{t-1}+ \\
& +\rho_{2} \vartheta_{t-2}+\rho_{3} \vartheta_{t-3}+\theta_{1} \epsilon_{t-1}+\theta_{2} \epsilon_{t-2}
\end{aligned}
$$

where $y_{\mathrm{t}}$ refers to teen rooms sales, $M_{\mathrm{j}, \mathrm{t}}$ month of the year, $C C I_{\mathrm{t}}, C C I, P P I_{\mathfrak{t}}, P P I$ and $V_{\mathrm{t}}$ number of vacation days. $\rho_{\mathrm{p}}$ and $\theta_{\mathrm{q}}$ are the model parameters for the autoregressive and moving average terms, respectively, and $\varepsilon_{t}$ are the residual term representing random disturbances that cannot be predicted.

(3) The order of the autoregressive moving average (ARMA) terms was selected. EViews uses model selection to determine the appropriate ARMA order. The orders of AR and MA were limited to four. Model selection is a way of determining which type of model fits best a set of data and is often used to choose the best model for forecasting that data (EViews 10 tutorial, 2017). We used Akaike Information Criterion (AIC) in ARIMAX modeling process. As an example, the best ARMA terms for teen room sales were determined according to the AIC criteria. The results are given in Figure 7. The best ARMA term for this case is obtained as $(3,2)$. The same steps were followed for each furniture product to make transformations and select ARMA terms based on AIC values. Best ARMA terms and related ARIMAX models with some model performance measures such as $R^{2}$, adjusted $R^{2}$ and $A I C$ are given in Table 3 .

The plots of actual versus forecasted values for ARIMAX models are provided by means of the EViews as shown in Figure 8. The results show that using the ARIMAX model is an applicable choice for forecasting monthly sales of the products in the observed furniture factory. The MAPE value of the armchair sales is calculated as $5.37 \%$, which means that a reasonable result is obtained (Çelik et al. 2016). On the other hand, MAPE values are also calculated for the sales of dining room, bedroom, teen room and sitting group as 10.36 $\%, 8.70 \%, 10.67 \%$ and $8.04 \%$, respectively.

The ARIMAX-ANN hybrid model integrated the ARIMAX model with the neural network model and tested with the raw data. We built the hybrid ARIMAXANN model with the following input layers: (1) the dependent variables used in ARIMAX modeling, (2) the residuals of the ARIMAX model. This process is followed by data partition and normalization by minmax normalization method. A training and testing model based on ANN is then employed after determining the design architecture and network properties. A logistic input and output activation function are used. Three layers which include input, hidden and output

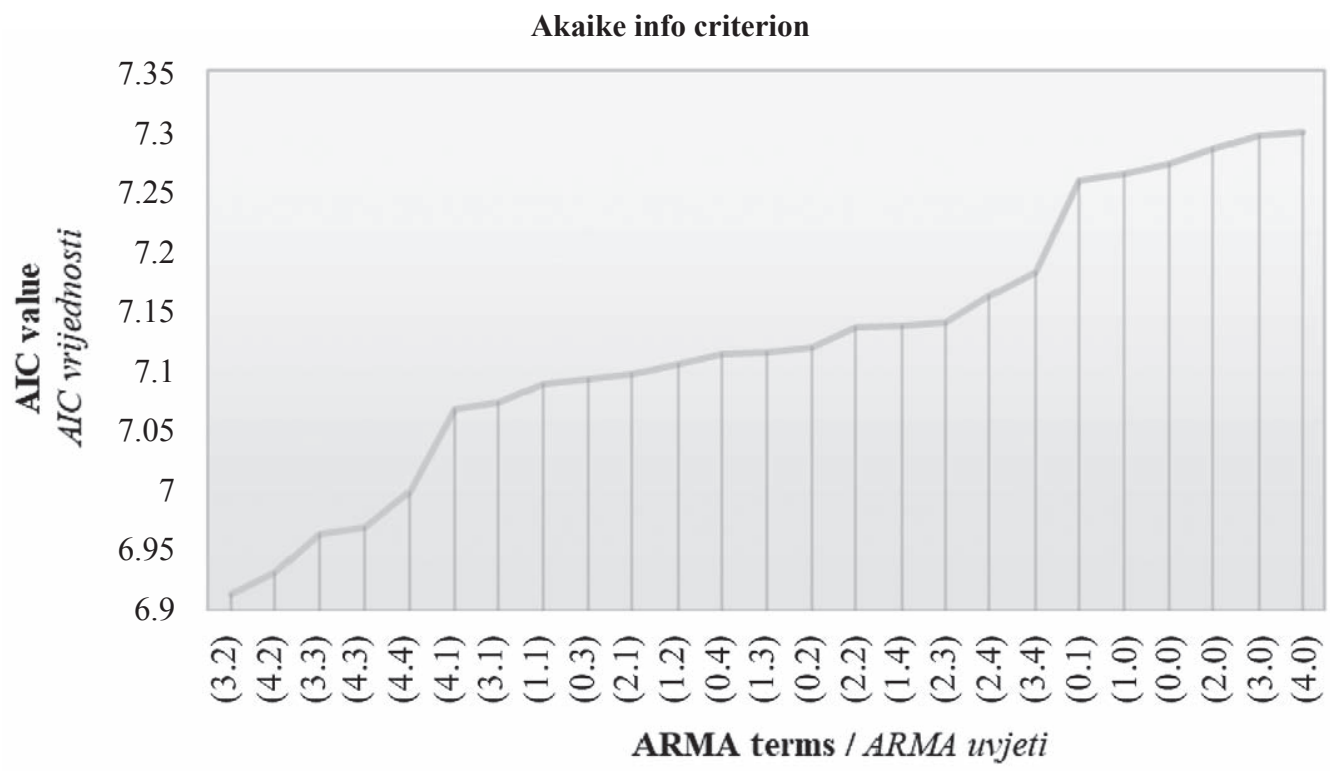

Figure 7 AIC values of ARMA terms proposed for teen room sales

Slika 7. AIC vrijednosti ARMA uvjeta predloženih za prodaju soba za mlade 
Table 3 Performance measurement results of ARIMAX models

Tablica 3. Rezultati performansi ARIMAX modela

\begin{tabular}{|l|c|c|c|c|c|}
\hline \multicolumn{1}{|c|}{ Model name / Model } & $\begin{array}{c}\text { Selected dependent } \\
\text { variable } \\
\text { Selektirana zavisna } \\
\text { varijabla }\end{array}$ & $\begin{array}{c}\text { ARIMAX model } \\
\text { representation } \\
\text { Prikaz modela } \\
\text { ARIMAX }\end{array}$ & $\begin{array}{c}\text { R-Squared } \\
R^{2}\end{array}$ & $\begin{array}{c}\text { Adj. } \\
\text { R-Squared } \\
\text { Prilagođeni } \\
R^{2}\end{array}$ & AIC \\
\hline $\begin{array}{l}\text { Dining room sales forecasting } \\
\text { predviđanje prodaje blagovaonica }\end{array}$ & D(DININGROOM) & $(2,1,4)$ & 0.726288 & 0.632059 & 8.057243 \\
\hline $\begin{array}{l}\text { Bedroom sales forecasting } \\
\text { predviđanje prodaje spavaćih soba }\end{array}$ & DLOG(BEDROOM) & $(3,1,4)$ & 0.616559 & 0.475964 & -1.552094 \\
\hline $\begin{array}{l}\text { Teen room sales forecasting } \\
\text { predviđanje prodaje soba za mlade }\end{array}$ & D(TEENROOM) & $(3,1,2)$ & 0.690860 & 0.591138 & 6.924504 \\
\hline $\begin{array}{l}\text { Sitting group sales forecasting } \\
\text { predviđanje prodaje namještaja za } \\
\text { sjedenje }\end{array}$ & DLOG(SITTINGGROUP) & $(0,1,3)$ & 0.690440 & 0.603376 & -2.015712 \\
\hline $\begin{array}{l}\text { Armchair sales Forecasting } \\
\text { predviđanje prodaje naslonjača }\end{array}$ & D(ARMCHAIR) & $(2,1,4)$ & 0.681010 & 0.571194 & 10.25667 \\
\hline
\end{tabular}
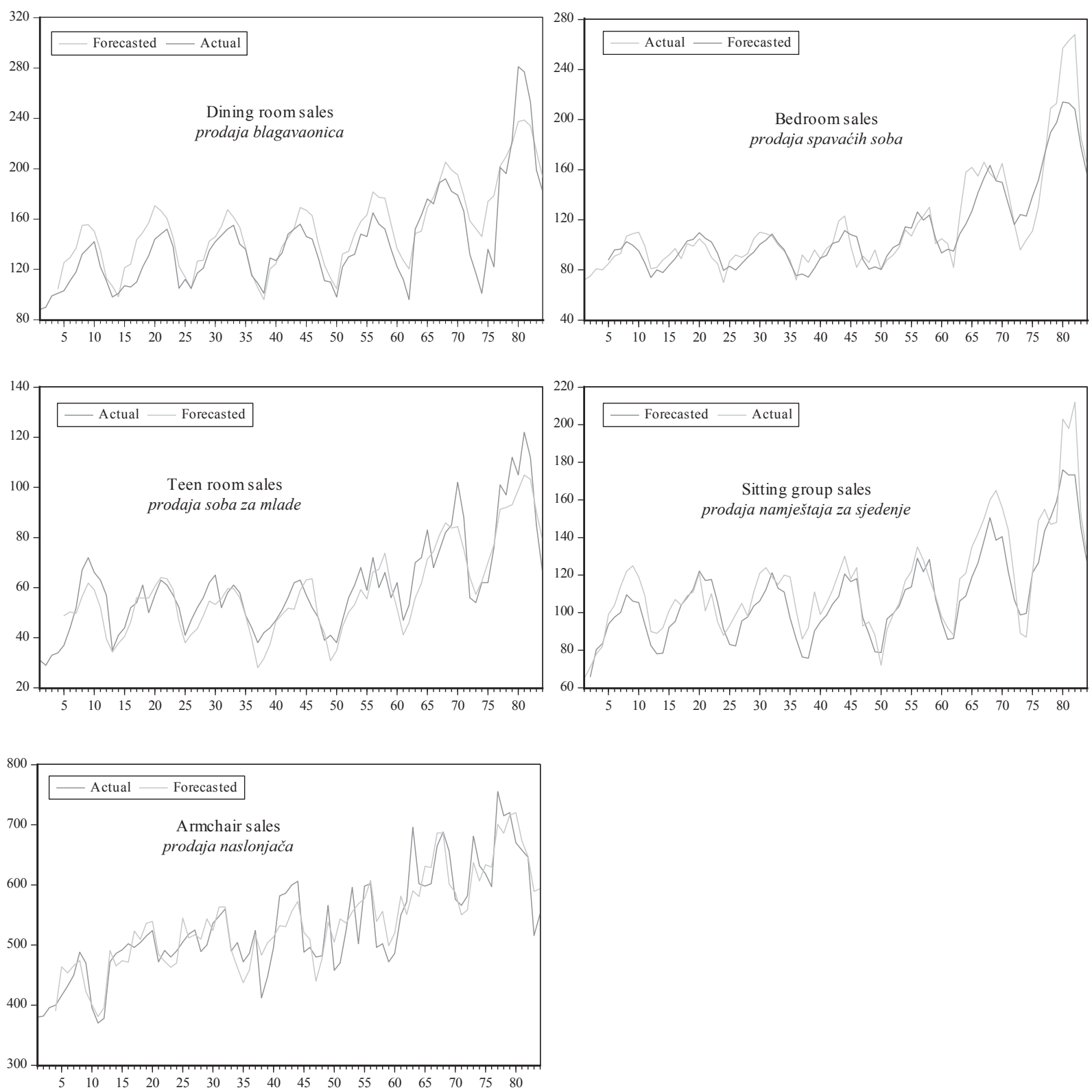

Figure 8 Comparison of actual and forecasted values for five furniture products by ARIMAX

Slika 8. Usporedba stvarnih i prognoziranih vrijednosti prodaje za pet proizvoda namještaja primjenom modela ARIMAX 


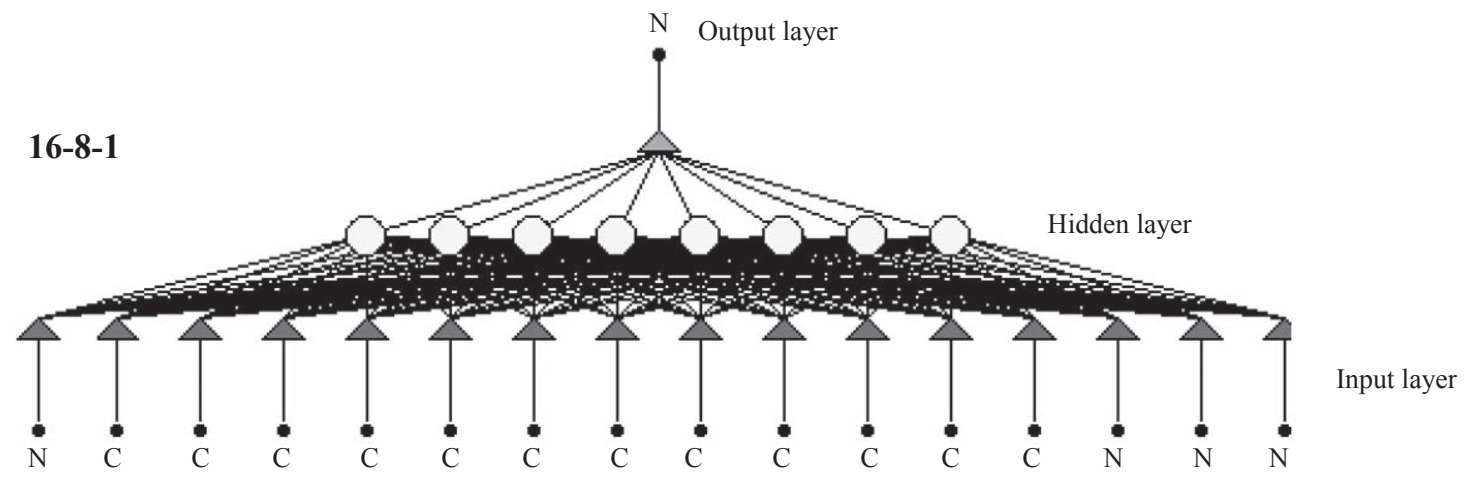

" $N$ " refers to numeric columns scaling parameters. " $C$ " refers to categorical column encoding parameters.

Figure 9 Network structure for teen room sales forecasting model ( $\mathrm{N}$ refers to numerical columns scaling parameters, $\mathrm{C}$ refers to categorical column encoding parameters)

Slika 9. Struktura mreže za prognostički model prodaje soba za mlade (N se odnosi na parametre skaliranja numeričkih stupaca, C se odnosi na parametre za kodiranje kategoriziranih stupaca)

layers are constituted. The network structure for hybrid ARIMAX-ANN based teen room sales forecasting model is presented in Figure 9. While "16" in input layer represents number of inputs (12 for month of the year variable and one for each of the four variables: CCI, PPI, number of vacation days and residuals of the ARIMAX model), " 8 " in hidden layer shows number of neurons with best accuracy value. " 1 " in output layer shows number of outputs. The accurateness of the model is directly related to the number of neurons in hidden layer. In this network, input and output activation functions are logistic. Output error function is sum-of-squares.

The performance indicator of $R^{2}$ is obtained as $98.97 \%$, which shows a good accurateness of the method. A commercial software, Alyuda NeuroIntelligence software, was used in developing the hybrid models. After the data entry to the software, it random-
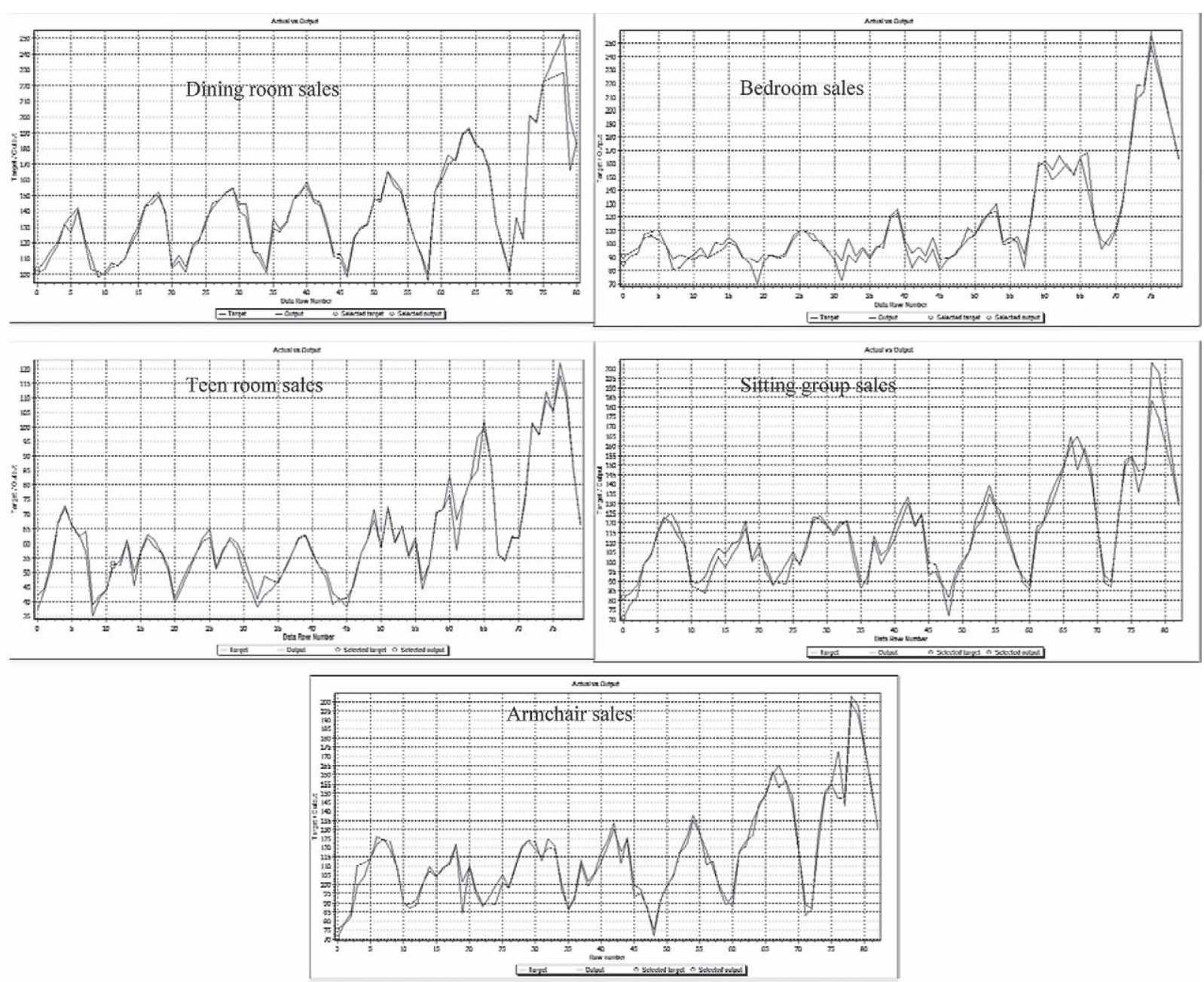

Figure 10 Comparison of actual and forecasted values for five furniture products by ARIMAX-ANN hybridization

Slika 10. Usporedba stvarnih i prognoziranih vrijednosti za pet vrsta namještaja primjenom hibridnog modela ARIMAX-ANN 
ly selects 70:15:15 ratios for training, validation and testing. In some studies, this ratio may be 60:20:20 (Fu et al., 2017). Experiments were run with various algorithms such as Quick Propagation, Quasi-Newton, Levenberg-Marquardt, Online Back Propagation and Conjugate Gradient Descent. The best network was obtained by Quick Propagation algorithm with some performance measures indicating as follows: while $R^{2}$ value is obtained as 0.9897 for all data set, the average test error is obtained as 3.621643. The MAPE value for overall and test data of this model was obtained as 3.22 $\%$ and $5.71 \%$, respectively.

The same steps were followed for each furniture product to develop hybrid models. The obtained MAPE values for overall and test data of the remaining four models (dining room, bedroom, sitting group and armchair) were obtained as, $1.99 \% \& 2.75 \%, 4.42 \% \&$ $4.47 \%, 3.66 \% \& 4.8 \%$ and $1.05 \%$ \& $2.71 \%$, respectively. The actual versus fitted values for these five models are given in Figure 10.

Results of ANN models, which were compared to the ARIMAX and ARIMAX-ANN hybrid models through this study, were derived from Yucesan et al. (2017). That study was carried out by the authors of this study. They applied ANN modeling based on Bayesian rules training. They obtained MAPE values of each furniture product sales forecasting as 3.588\%, $5.951 \%, 5.954 \%, 5.223 \%$ and $3.057 \%$, respectively, for dining room, bedroom, teen room, sitting group and armchair.

\subsection{Overall discussion}

\subsection{Rasprava rezultata}

The best model for this study was the ARIMAXANN hybrid model in each furniture product sales forecasting (see Table 4). Çelik et al. (2016) reported that, in practical applications, MAPE $<10 \%$ means high accuracy. Accordingly, it must be noted that MAPE values of ARIMAX-ANN hybridization and single ANN models for monthly furniture product sales figures are within the range reported by Çelik et al. (2016). Forecasting accuracy is dependent on the choice of forecasting model. ANN and ARIMAX models have different advantages and disadvantages. ARIMAX model is very flexible and it can also represent AR, MA, differencing and inclusion of external factors. ARIMAX model is very good when dealing with the linear part but it is weak when working with nonlinear data. ANN model is good at dealing with nonlinear parts. When using hybrid models, the residuals of the ARIMAX model as input variables can solve this problem. Also, the results show that a combination of ARIMAX and ANN models gives better forecasting accuracy.

\section{CONCLUSION \\ 4. ZAKLJUČAK}

In this study, a comparative forecasting framework was developed and applied to solve the problem of sales forecasting for furniture products. The applied models include ARIMAX, ANN and ARIMAX-ANN hybridization. The models were used to forecast monthly sales figures of a corporate furniture manufacturing company located in Black Sea region of Turkey. In conclusion of this comparative study, the results of performance measures demonstrate that ARIMAX-ANN hybrid model, developed for each amount of product sales, gives better accuracy values than single models. Overall, it is proved that using the ARIMAX and hybridization of this method with ANN are applicable for forecasting monthly sales of furniture products.

The aim of sales forecasting is to determine the demand level of products in a certain time horizon and it is an important part of production planning. In aggregate production planning, sales forecasting is the starting point. This step is one of the most challenging problems for stakeholders in furniture industry. Decision makers should evaluate the costs and benefits of each model before choosing an appropriate forecasting method. In our opinion, the ARIMAX-ANN hybrid model was suitable for the observed company since this method gives effective solutions. This comparative framework can be adapted to any company competing in forestry industry or other industries. In addition to its methodological contributions, this study has some benefits for the forestry industry. First, it further encourages stakeholders to forecast sales figures in other forestry products such as timber, parquet, oriented

Table 4 MAPE values for five models with respect to three methodologies

Tablica 4. MAPE vrijednosti za pet modela s obzirom na tri metodologije

\begin{tabular}{|l|c|c|c|c|}
\hline \multirow{2}{*}{ Model name / Model } & \multicolumn{4}{c|}{ MAPE values, \% } \\
\cline { 2 - 5 } & ARIMAX & ANN (Yucesan et al. 2017) & $\begin{array}{c}\text { All data } \\
\text { Svi podatci }\end{array}$ & $\begin{array}{c}\text { Test data } \\
\text { Podatci testa }\end{array}$ \\
\hline $\begin{array}{l}\text { Dining room sales forecasting } \\
\text { predviđanje prodaje blagovaonica }\end{array}$ & 10.36 & 3.58 & 1.99 & 2.75 \\
\hline $\begin{array}{l}\text { Bedroom sales forecasting } \\
\text { predviđanje prodaje spavaćih soba }\end{array}$ & 8.70 & 5.95 & 4.42 & 4.47 \\
\hline $\begin{array}{l}\text { Teen room sales forecasting } \\
\text { predviđanje prodaje soba za mlade }\end{array}$ & 10.67 & 5.95 & 3.22 & 5.71 \\
\hline $\begin{array}{l}\text { Sitting group sales forecasting } \\
\text { predvidanje prodaje namještaja za sjedenje }\end{array}$ & 8.04 & 5.22 & 3.66 & 4.8 \\
\hline $\begin{array}{l}\text { Armchair sales forecasting } \\
\text { predviđanje prodaje naslonjača }\end{array}$ & 5.37 & 3.06 & 1.05 & 2.71 \\
\hline
\end{tabular}


standard board, plywood, etc. Secondly, advanced manufacturing methods have been increasingly employed in forestry sector due to today's technological development. Due to the possible demand for wood products, comprehensive and effective forecasting approaches are required for monitoring the trend. Therefore, a comparative forecasting outline has been developed, and it has been used to forecast the sales figures for furniture industry in Turkey.

By the current research, the model proposed by Yucesan et al. (2017) was improved by developing a more effective hybrid model. In future, the authors are planning to extend the hybrid model considering external factors to provide a more accurate result, although it has not been considered in this particular case study.

\section{REFERENCES}

\section{LITERATURA}

1. Akkoyunlu, M. T.; Akkoyunlu, M. C.; Pusat, S.; Özkan, C., 2015: Prediction of accurate values for outliers in coal drying experiments. Arabian Journal for Science and Engineering, 40 (9): 2721-2727.

http://dx.doi.org/ 10.1007/s13369-015-1746-2.

2. Alon, I.; Qi, M.; Sadowski, R. J., 2001: Forecasting aggregate retail sales: a comparison of artificial neural networks and traditional methods. Journal of Retailing and Consumer Services, 8 (3): 147-156.

http://dx.doi.org/10.1016/S0969-6989(00)00011-4.

3. Anggraeni, W.; Vinarti, R. A.; Kurniawati, Y. D., 2015: Performance Comparisons Between Arima and Arimax Method in Moslem Kids Clothes Demand Forecasting: Case Study. Procedia Computer Science, 72: 630-637. https://doi.org/10.1016/j.procs.2015.12.172.

4. Areekul, P.; Senjyu, T.; Toyama, H.; Yona, A., 2010: Notice of violation of IEEE publication principles a hybrid ARIMA and neural network model for short-term price forecasting in deregulated market. IEEE Transactions on Power Systems, 25 (1): 524-530.

https://doi.org/10.1109/TPWRS.2009.2036488.

5. Arunraj, N. S.; Ahrens, D., 2015: A hybrid seasonal autoregressive integrated moving average and quantile regression for daily food sales forecasting. International Journal of Production Economics, 170: 321-335. https://doi.org/10.1016/j.ijpe.2015.09.039.

6. Arya, P.; Paul, R. K.; Kumar, A.; Singh, K. N.; Sivaramne, N.; Chaudhary, P., 2015: Predicting pest population using weather variables: an ARIMAX time series framework. International Journal of Agricultural and Statistics Sciences, 11 (2): 381-386.

7. Bierens, H. J., 1987: ARMAX model specification testing, with an application to unemployment in the Netherlands. Journal of Econometrics, 35 (1): 161-190. https://doi.org/10.1016/0304-4076(87)90086-8.

8. Çelik, Ö.; Teke, A.; Yıldırım, H. B., 2016: The optimized artificial neural network model with Levenberg - Marquardt algorithm for global solar radiation estimation in Eastern Mediterranean Region of Turkey. Journal of Cleaner Production, 116: 1-12.

http://dx.doi.org/10.1016/j.jclepro.2015.12.082.

9. Doganis, P.; Alexandridis, A.; Patrinos, P.; Sarimveis, H., 2006: Time series sales forecasting for short shelf-life food products based on artificial neural networks and evolutionary computing. Journal of Food Engineering, 75 (2): 196-204. https://doi.org/10.1016/j.jfoodeng.2005.03.056.

10. Fabianová, J.; Kačmáry, P.; Molnár, V.; Michalik, P., 2016: Using a Software Tool in Forecasting: A Case Study of Sales Forecasting Taking into Account Data Uncertainty. Open Engineering, 6 (1): 270-279. https://doi.org/10.1515/eng-2016-0033.

11. Fan, J.; Shan, R.; Cao, X.; Li, P., 2009: The analysis to tertiary-industry with ARIMAX model. Journal of Mathematics Research, 1 (2): 156.

12. Fu, Z.; Avramidis, S.; Zhao, J.; Cai, Y., 2017: Artificial neural network modeling for predicting elastic strain of white birch disks during drying. European Journal of Wood and Wood Products, 75: 949-955. https://doi.org/10.1007/s00107-017-1183-x.

13. Gul, M.; Guneri, A. F., 2016a: Planning the future of emergency departments: Forecasting ED patient arrivals by using regression and neural network models. International Journal of Industrial Engineering: Theory, Applications and Practice, 23 (2): 137-154.

14. Gul, M.; Guneri, A. F., 2016b: An artificial neural network-based earthquake casualty estimation model for Istanbul city. Natural hazards, 84 (3): 2163-2178. http://dx.doi.org/ 10.1007/s11069-016-2541-4.

15. Gul, M.; Guneri, A. F., 2015: Forecasting patient length of stay in an emergency department by artificial neural networks. Journal of aeronautics and space technologies (Havacilik ve uzay teknolojileri dergisi), 2 (8): 1-6. http://dx.doi.org/ 10.7603/s40690-015-0015-7.

16. Guneri, A. F.; Gumus, A. T., 2008: Artificial neural networks for finite capacity scheduling: a comparative study. International Journal of Industrial Engineering: Theory, Applications and Practice, 15 (4): 349-359.

17. Guneri, A. F.; Gumus, A. T., 2008: The usage of artificial neural networks for finite capacity planning. International Journal of Industrial Engineering: Theory, Applications and Practice, 15 (1): 16-25.

18. Hazır, E.; Koç, K. H.; Esnaf, Ş., 2016: Türkiye mobilya satış değerlerinin örnek bir yapay zekâ uygulaması ile tahmini. Selçuk-Teknik Dergisi, 1172-1182.

19. Jalalkamali, A.; Moradi, M.; Moradi, N., 2015: Application of several artificial intelligence models and ARIMAX model for forecasting drought using the Standardized Precipitation Index. International Journal of Environmental Science and Technology, 12 (4): 12011210. https://doi.org/10.1007/s13762-014-0717-6.

20. Jansen, W. J.; Nahuis, N. J., 2003: The stock market and consumer confidence: European evidence. Economics Letters, 79 (1): 89-98. http://dx.doi.org/10.1016/S0165-1765(02)00292-6.

21. Khashei, M.; Bijari, M., 2010: An artificial neural network (p, d, q) model for timeseries forecasting. Expert Systems with applications, 37 (1): 479-489. https://doi.org/10.1016/j.eswa.2009.05.044.

22. Kröse, B.; Krose, B.; van der Smagt, P.; Smagt, P., 1993: An introduction to neural networks. CRC Press, London.

23. Kuo, R. J., 2001: A sales forecasting system based on fuzzy neural network with initial weights generated by genetic algorithm. European Journal of Operational Research, 129 (3): 496-517. https://doi.org/10.1016/S0377-2217(99)00463-4.

24. Kuo, R. J.; Wu, P.; Wang, C. P., 2002: An intelligent sales forecasting system through integration of artificial neural networks and fuzzy neural networks with fuzzy weight elimination. Neural Networks, 15 (7): 909-925. http://dx.doi.org/10.1016/S0893-6080(02)00064-3.

25. Lee, M.; Hamzah, N., 2010: Calendar variation model based on ARIMAX for forecasting sales data with Rama- 
dhan effect. In Proceedings of the Regional Conference on Statistical Sciences, pp. 349-361.

26. Luxhøj, J. T.; Riis, J. O.; Stensballe, B., 1996: A hybrid econometric - neural network modeling approach for sales forecasting. International Journal of Production Economics, 43 (2): 175-192. https://doi.org/10.1016/0925-5273(96)00039-4.

27. Mahbub, N.; Paul, S. K.; Azeem, A., 2013: A neural approach to product demand forecasting. International Journal of Industrial and Systems Engineering, 15 (1): 1-18. http://dx.doi.org/10.1504/IJISE.2013.055508.

28. Murlidharan, V.; Menezes, B., 2013: Frequent pattern mining-based sales forecasting. Opsearch, 50 (4): $455-$ 474. https://doi.org/10.1007/s12597-012-0119-9.

29. Oblak, L.; Stirn, L. Z.; Moro, M.; Hrovatin, J.; Mole, S.; Kuzman, M. K., 2012: Choice of Quantitative Method for Forecasting of Parquet Sales. Drvna industrija, 63 (4): 249-254. http://dx.doi.org/10.5552/drind.2012.1204.

30. Onat, O.; Gul, M., 2018: Application of Artificial Neural Networks to the prediction of out-of-plane response of infill walls subjected to shake table, 21 (4): 521-535. http://dx.doi.org/10.12989/sss.2018.21.4.521.

31. Peltzman, S., 2000: Prices rise faster than they fall. Journal of Political Economy, 108 (3): 466-502. http://dx.doi.org/ 10.1086/262126.

32. Pusat, S.; Akkoyunlu, M. T.; Pekel, E.; Akkoyunlu, M. C.; Özkan, C.; Kara, S. S., 2016: Estimation of coal moisture content in convective drying process using ANFIS. Fuel Processing Technology, 147: 12-17. http://dx.doi.org/10.1016/j.fuproc.2015.12.010.

33. Somoza, E.; Somoza, J. R., 1993: A neural-network approach to predicting admission decisions in a psychiatric emergency room. Medical Decision Making, 13 (4): 273 280. http://dx.doi.org/ 10.1177/0272989X9301300402.

34. Sutthichaimethee, P.; Ariyasajjakorn, D., 2017: Forecasting Energy Consumption in Short-Term and Long-Term Period by Using Arimax Model in the Construction and Materials Sector in Thailand. Journal of Ecological Engineering, 18 (4) http://dx.doi.org/ 10.12911/22998993/74396.
35. Xu, Q.; Tsui, K. L.; Jiang, W.; Guo, H., 2016: A hybrid approach for forecasting patient visits in emergency department. Quality and Reliability Engineering International, 32 (8): 2751-2759.

http://dx.doi.org/10.1002/qre.2095.

36. Yip, D. H.; Hines, E. L.; Yu, W. W., 1997: Application of artificial neural networks in sales forecasting. Proceedings of International Conference on Neural Networks (ICNN'97), IEEE, Vol. 4, pp. 2121-2124. http://dx.doi.org/ 10.1109/ICNN.1997.614233.

37. Yucesan, M.; Gul, M.; Celik, E., 2017: Application of artificial neural networks using bayesian training rule in sales forecasting for furniture industry. Drvna industrija: znanstveni časopis za pitanja drvne tehnologije, 68 (3): 219-228. http://dx.doi.org/10.5552/drind.2017.1706.

38. Zhang, G. P., 2003: Time series forecasting using a hybrid ARIMA and neural network model. Neurocomputing, 50: 159-175. https://doi.org/10.1016/S0925-2312(01)00702-0.

39. *** 2013: TOBB. Turkey Furniture Products Council Industry Report, TOBB Publication No: 2014/212, https://www.tobb.org.tr/Documents/yayinlar/2014/mobilya_sektor_raporu_tr_int.pdf.

40. *** 2017: EViews 10 tutorial., http://www.eviews.com/ Learning/basics.html.

\section{Corresponding address:}

Asst. Prof. MELIH YUCESAN, Ph.D.

\author{
Munzur University \\ Engineering Faculty \\ Department of Mechanical Engineering \\ 62000 Tunceli, TURKEY \\ e-mail: melihyucesan@munzur.edu.tr
}

